\title{
IOPAS AGAIN
}

\begin{abstract}
Replying to T. E. Kinsey's remarks on my article in EMERITA 49, 1981, 17-25, I maintain that Iopas' song (Aen. I 740-7) contains a vision of a disturbed cosmic order appropriate to the dangerous erotic atmosphere around Dido and Aeneas here and that it contrasts significantly with the world-order depicted in Anchises' speech of Aen. VI. Atlas, as Iopas' teacher, belongs to a similarly ambiguous image of cosmic and natural order: cf. Aen. IV 246-51. An addendum calls attention to James Joyce's use of Iopas' didacticism in Ulysses.
\end{abstract}

The editors of EMERITA graciously sent me the above reply which T. E. Kinsey made to my criticism of his 1979 essay on the Song of Iopas, a piece which I had criticized in EMERITA 49, 1981, for misleading statements about an earlier study of mine on the Song published in Hermes 99, 1971, pp. 336-49. Tedious and distasteful as polemic is, I find it necessary to clarify again some of the points made in 1981. I shall do so with all possible brevity, following the order of Kinsey's arguments above.

Proem. I nowhere accuse K. of «irresponsibility for expressing an opinion...", erroneous or otherwise. My criticism of his lack of aresponsibilityn on p. 23 of my 1981 article refers strictly to his failure to acknowledge my criticisms of $\mathrm{Kranz}$ and to distinguish sufficiently between Kranz's interpretation of the song of Iopas and my own, a point to which I shall have to return later. In noting K.'s erratic citation of his debt to Austin's edition of Aeneid I, I hardly meant to imply that a scholar of K.'s stature was using a standard commentary without acknowledgement, but rather to call attention to his rather casual way of citing his sources. The normal way of indicating the kind of indebtedness that K. owes Austin in this passage (K., 1979, p. 80) would be quotation marks followed immediately by a footnote. K.'s reference to LII, $1^{\circ}-6$ 
Austin seven lines after an unmarked nearly verbatim citation does not make immediately clear what is his and what is his predecessor's. K.'s three previous references to Austin, incidentally, all come in the middle, not at the end, of a paragraph, and two come in the midst of a sentence, so that his procedure on p. 80 is, at the least, confusing. As not every reader can check every reference, the author does have responsibility for utmost clarity in such matters.

Atlas. (I a). K. continues to oversimplify what I wrote about Atlas in 1971, p. 344, viz.: "It may well be, as interpreters have suggested, that Atlas is Iopas' teacher partly because of his associations with the African mountains of that name and, more important, because he 'seems to have been a sort of mythical representative or progenitor of physical philosophers", a statement for which I cited Conington, Heyne, and Kranz. K. himself fails to mention the chronological difficulty in Atlas' teaching Iopas, a problem which lies behind the reading quae docuit Atlas preferred by Servius. I hardly think that "picturesqueness" (the last refuge of the baffled interpreter) will account for the description of Atlas in IV 246-51; and I continue to think that Atlantis duri caelum qui uertice fulcit... justifies seeing in Virgil's account the "harsh outlaw" familiar to us from Greek mythology. The fact that the teacher of Iopas is associated with this harsh aspect of nature is not, I suggest, irrelevant to the view of nature implicit in the pupil's song.

I did not, incidentally, anywhere deny the «imposing figure» of Iopas. I too had observed the parallel with crinitus Apollo (1971, p. 340, note 2). But note that crinitus is also the epithet of Turnus' helmet with its fire-breathing chimaera, in VII 785 .

I b). K.'s attempt to distinguish between "appearance» and "reference» hardly eliminates his distortion or misquotation of my remark about music in the Aeneid (1981, p. 22). Accuracy of quotation is, to repeat, a responsibility of the author. Nor is my phrase "unfortunate bit of cannon fodder" meant to be "contemptuous". One feels sorry for "cannon fodder", as Virgil seems to have; one does not necessarily feel "contempt" for them.

I c). In $1979 \mathrm{~K}$. wrote, "Segal sees the Song of Iopas as evidence of Carthaginian decadence for two further reasons" (p. 85). Now he writes (above), "I did not attribute the word 'decadence' to Segal and what I meant by 'decadence' had already been made sufficiently clear by words some of which Segal does use». Here he is attempting to deny 
what is simply there on the page in black and white. In fact he used the word "decadence» four times in less than twenty lines $(1979$, p. 85$)$; I never used it once. To me the word has a strong and precise meaning. By using it to characterize my argument, even by association, $\mathrm{K}$. has distorted that argument.

I d). I agree with Kranz's 1953 study of Iopas on one specific point, which amounts to precisely one paragraph of his essay, a paragraph of which I quoted the lead sentence on p. 341 of my 1971 article. Kranz's major point was that Virgil uses the sun and moon in the song as an ethnographic characterization of Carthaginian/Phoenician worship of those celestial bodies. When I went to some pains to criticize that much more fully developed point and when $\mathrm{K}$. makes a similar criticism of Kranz in 1979 without mentioning my article, I continue to find it an unfair misrepresentation to say that «in general (I) follow Kranz». If $K$. meant that in this one single point, but not in others, I "follow Kranz", that is certainly not what his 1979 printed text says. Precisely this carelessness of reference, omission of qualifications, failure to mention points similar to his own by scholars whom he criticizes for other matters, and blurring of distinctions incurred my previous charge of lack of "discrimination and responsibility».

Kranz's remark on "Orientalische Grössenverhältnisse, orientalische Pracht», RhM 96, 1953, p. 37, which I cited with approval in 1971, is a far cry from «decadence». That paragraph of Kranz's article seems to me still convincing in pointing out, in careful detail, the impression of luxury surrounding Iopas and his queen. K., incidentally, also fails to mention Kranz's criticism of Pöschl, along with mine, in his discussion of "symbolical" interpretations, 1979, pp. 82-84; see Kranz, p. 34 f. and my 1971 essay, p. 337.

I fail to understand how K. can speak of Georgics II 479 as containing "primarily land disasters» when the second half of the verse is qua ui maria alta tumescant.

II a). K. confuses issues. Obviously I believe in the importance of Iopas. But I do not believe that the kind of subjectivizing, psychologizing probing for motives or imputing thoughts or aims that $\mathrm{K}$. implied on pp. 81-2 of his 1979 essay is legitimate for a figure who appears for half a dozen lines and never again. Such a figure may be quite important in a narrative without having to be «brought alive" or given psychological depth. The psychological realism of the nineteenth-century novel is not everywhere appropriate. 
II b) $\mathrm{K}$. in no way convinces me that when we speak of the race of men we necessarily stress the unity of mankind. A song about the origins of hominum genus et pecudes does not to me sound promising for "the unity of men». Had such been Virgil's thought, one would expect a more emphatic expression (e. g. IV 522 ff.).

II c). To use the word "symbol" before some classicists is like waving a red flag before an irascible bull. Regrettably my modest attempt to repeat the long-established distinction between symbol and allegory got lost amid the dust of the charge. K.'s tone of vituperative scorn in his last paragraph can only raise more dust. He again oversimplifies the points I make in the second two paragraphs on p. 24 of my 1981 paper, in which I attempt to recognize the multilayered meaning, the evocative quality, the atmospheric richness (the Heinzean Stimmung) of Virgil's poetry without the "one-to-one equations of the type (rather misleadingly) called 'symbolic'" that I objected to in Pöschl's approach to the passage (though Pöschl himself often transcends this approach elsewhere). Given the heavy emphasis I place on textual evidence, K.'s anxiety about a licence for riotous symbolism is misplaced.

III). K.'s objection to my comparison of the views of the natural order implicit in the song of Iopas and in the prophecy of Anchises in book VI rests on a quibble. Of course, as K. says, Virgil "gives us only the subjects of Iopas' song». But, as we both have argued, these "subjects" have a pattern, expression, and content that reveal a conception of the world order that they describe. K. himself spoke of "the picture of the Universe given by Iopas" $(1979$, p. 78$)$ and admits that Iopas "sings of a Universe of toil and uncertainty" (p. 79) - a point on which I am happy to share his opinion. I continue to think it valid to extrapolate a view of nature from the song of Iopas, particularly as it carries echoes of the cosmogonic-scientific poetry of Orpheus in Argonautica I, of Lucretius, and of Virgil himself in the Georgics. Comparison with the other major interpreter of the natural order in the first half of the poem seems to me entirely within the compass of a literary study of the Aeneid.

$\mathrm{K}$.'s remark on fire in the Anchises passage seems to me hardly a relevant objection to the contrast I sought to establish between the two "cosmologies». It suffices for my purposes that the fire of VI has a purifying function, in close association with the celestial or divine elements: so VI $730,742,747$. Surely we are to think of this fire as 
the Stoic cosmic principle, as VI $724 \mathrm{ff}$. indicate. See Norden's commentary on VI $726,729,730,731$, citing, among other references, Cic. Nat. Deor. II 41-42 and Varro, Sat. 268.

IV). I did not cite any textual support for my suggestion (not, I think, remarkably original) that Virgil was concerned to separate the Trojan Aeneadae from "the defeated Eastern people from whom (the Romans) arose" because the matter was incidental to the immediate questions and one or two passages had already been cited. I may now adduce the following: I 283-87, IV 215-17, IX 597-99, 616-20, 642-44, X 88-95, XII $99 \mathrm{f}$.

Note 5). My omission of the comma after concha in VI 171 was an inadvertence, of very minor consequence and, so far as I can see, of no bearing on the issues here. To say, as $\mathrm{K}$. does, that such punctuation "makes nonsense of the lines" is wild exaggeration. Not that I want to defend that punctuation, but it in fact occurs in the edition of Ruaeus (ad usum serenissimi Delphini), whose many generations of users presumably did not find it nonsense.

Note 8). By partial quotation K. makes it "appear" as if I am mistranslating VI 746-47. The full context there on p. 21, however, with the inclusive reference "VI 724-51", makes it clear that by "leaving that pure celestial fire" I mean the soul's reunion with the earthly substance for its reascent to this life in $750 \mathrm{f}$. ("the dross of earthly life», p. 21).

Apropos of mistranslation, there seem to be one on p. 80 of K.'s 1979 essay, for he takes lines $748 \mathrm{f}$., nec non et uario noctem sermone trahebat / infelix Dido, as describing the effect of Iopas' song on Dido, whereas surely the lines refer to the entire banquet, Aeneas' and Ascanius / Cupid's presence included. To focus them so narrowly on Iopas' song is to lose perspective.

Note 8). When K. reminds us, parenthetically, that "Aeneas... incidentally was not Rome's founder", is he proposing a new reading for Aen. I 5 (cf. also I 33, XII 166, 190-94) or just being pedantic (I 262 ff.)?

Addendum. I take this opportunity to mention a curiosity totally unrelated to the above controversy but perhaps of interest for the Nachleben of our crinitus Iopas: a passage in James Joyce's Ulysses (Bodley Head, new edition, London 1960), p. 408: 
Hairy Iopas, says the citizen, that exploded volcano, the darling of all countries and the idol of his own. So Joe starts telling the citizen about the foot and mouth disease and the cattle traders and taking action in the matter and the citizen sending them all to the right-about and Bloom coming out with his sheepdip for the scab and a hoose drench for coughing calves and the guaranteed remedy for timber tongue.

As Iopas becomes more hirsute, his wisdom becomes rather more earthy and practical.

Charles Segal 